\author{
МЕЖДУНАРОДНЫЙ «КРУГЛЫЙ СТОЛ» \\ НА ТЕМУ «150 ЛЕТ ПРОДАЖИ АЛЯСКИ \\ И РОССИЙСКО-АМЕРИКАНСКИЕ ОТНОШЕНИЯ» \\ (MOCKBA, MAPT 2017 г.)
}

\title{
А.Ю. Петров
}

Международный «круглый стол», приуроченный к 150-летию уступки Аляски США. Приводятся полные тексты приветствий научного руководителя Института всеобщей истории РАН (ИВИ РАН), академика РАН А.О. Чубарьяна, директора ИВИ РАН, профессора РАН М.А. Липкина, руководителя Центра североамериканских исследований ИВИ РАН, профессора В.В. Согрина, Посла США в России Дж. Теффта. На «круглом столе» выступил профессор Калифорнийского университета А. Коэн. Свои доклады представили участники из ряда регионов Российской Федерации. Принято решение продолжить проведение подобных мероприятий.

Ключевые слова: Русская Америка, история, российско-американские отношения, Россия, США, Аляска, Калифорния, колонизация, Русская Православная Церковь

International «round table», dedicated to the $150^{\text {th }}$ anniversary of the concessions of Alaska USA. The full text of the greetings scientific Director of the Institute of World history, Russian Academy of Sciences (IVI RAS), Academician A.O. Chubarian, Director of the IVI RAS, Professor of the Russian Academy of Sciences M.A. Lipkin, Director of the Center for North American studies, IVI RAS, Professor V. V. Sogrin, Ambassador of the United States of America to the Russian Federation John Tefft. Professor from California State University A. Cohen delivered his report. Presentations from participants from a number of regions of the Russian Federation were delivered at the round table. It was decided to continue such events in the future.

Key words: Russian-America / Russian America, Russian-American relations, history, Russia, USA, Alaska, colonization, Russian Orthodox Church

Исследование выполнено за счет гранта Российского научного фонда (проект № 1718-01567). 
ридцатого марта 2017 года исполнилось 150 лет со дня продажи Аляски Соединенным Штатам Америки. Этому знаменательному событию, полтора века назад изменившему картину мира и ставшему причиной уникального социокультурного явления, имевшего важные последствия для обеих стран, было посвящено заседание международного «круглого стола» на тему «150 лет продажи Аляски и российско-американские отношения». Семинар состоялся в начале марта в Москве, в Институте всеобщей истории РАН (ИВИ РАН) и был организован группой по изучению истории Русской Америки Центра североамериканских исследований ИВИ РАН.

Юбилейный круглый стол прошел в открытом расширенном формате - его участниками стали более 30 гостей из США, Москвы, С.-Петербурга, Вологды, Рязани, Петропавловска-Камчатского: научные сотрудники, работники архивов, студенты, представители общественности, журналисты. В ходе семинара прозвучало 12 выступлений.

Мероприятие открыл научный руководитель ИВИ РАН, академик РАН А.О. Чубарьян, который, приветствуя участников международного «круглого стола», отметил, что тема 150-летия продажи Аляски и ее связи с развитием российско-американских отношений является одной из центральных в деятельности Института всеобщей истории РАН.

Директор ИВИ РАН, доктор исторических наук, профессор РАН М.А. Липкин поблагодарил организационный комитет международного «круглого стола», всех волонтеров и помощников, а также всех оказавших поддержку в проведении этого международного научного форума.

На заседании «круглого стола» были заслушаны приветствия российских и американских официальных лиц, в частности, посла США в Москве Дж. Теффта.

С приветствием к участникам и гостям обратился руководитель Центра североамериканских исследований ИВИ РАН, доктор исторических наук, главный научный сотрудник, профессор В.В. Согрин, который отметил: средства массовой информации активизировались в связи с юбилеем, так что мы во всех смыслах «попали в самую точку».

Кроме известных ученых, доклады которых публикуются, в заседании «круглого стола» приняли участие студенты Московского государственного лингвистического университета (МГЛУ). Они высоко оце- 
нили данный «круглый стол» и высказались за продолжение взаимодействия с МГЛУ и другими вузами, подчеркнув, что изучение истории США, Русской Америки и российско-американских отношений представляет большой интерес для студенческих аудиторий.

В заключение хотелось бы отметить, что участники «круглого стола» предложили проводить научные мероприятия по истории и наследию Русской Америки регулярно, а студенты высказались за образование студенческого кружка, в котором бы обсуждались заинтересовавшие их вопросы. 